\title{
A Meta-Analysis of Intervention Trials Examining the Effects of A Simple 2-Week Weight Loss Program on Body Weight and Waist Circumference
}

\author{
Paige Gianturco and Vanessa Perez* \\ Exponent, Health Sciences, Center for Epidemiology, Biostatistics, and Computational Biology, Chicago
}

\begin{abstract}
Received: December 11, 2015; Accepted: January 18, 2016; Published: January 28, 2016
*Corresponding authors: Vanessa Perez, Exponent, 525 West Monroe Street, Suite 1050, Chicago, IL 60661, Tel: + 562-554-9103; E-mail: perezvaness@gmail.com
\end{abstract}

\begin{abstract}
Background: Relatively faster initial weight loss may enhance participant motivation to adhere to a longer-term weight reduction or maintenance plan and overall healthier lifestyle. The Special $\mathrm{K}$ Challenge $^{\mathrm{TM}}$ is a portion-controlled, 2-week program that recommends replacement of two meals per day with ready-to-eat cereal and incorporation of portion-controlled snacks, fruits, and vegetables to help participants either begin a weight loss program or attain short-term weight loss for ongoing weight maintenance efforts. The objective of this meta-analysis is to examine the effects of a shortterm weight loss program on body weight and waist circumference in ten trials conducted across seven countries.
\end{abstract}

Methods: Random effects meta-analyses generating weighted mean differences in body weight and waist circumference from baseline to 2-weeks (within-group analyses) and comparing intervention to control, where applicable.

Results: The Special $\mathrm{K}$ Challenge $\mathrm{T}^{\mathrm{TM}}$ intervention resulted in statistically significant weighted mean reductions in body weight $(-1.61 \mathrm{~kg}, 95 \% \mathrm{CI}:-1.85,-1.37)$ and waist circumference $(-2.19 \mathrm{~cm}$, $95 \%$ CI: $-2.72,-1.66)$ in the within-group analyses. Compared to the control group, the Special $\mathrm{K}$ Challenge $\mathrm{TM}^{\mathrm{M}}$ intervention resulted in a statistically significant decrease in body weight $(-1.43 \mathrm{~kg}, 95 \% \mathrm{CI}$ : $-2.10,-0.76)$ and waist circumference $(-1.20 \mathrm{~cm}, 95 \% \mathrm{CI}:-2.20,-0.20)$. Two subgroups analyses, one among women only and one by readyto-eat-cereal serving size, were consistent with these findings.

Conclusion: Overall, successful short-term weight loss was achieved, demonstrating that a simple, energy-reduced program with calorie-controlled meals and snacks is an effective approach to attain short-term weight loss and reduce waist circumference among overweight individuals.

Keywords: Meta-Analysis; Breakfast Cereals; Weight Loss; Waist Circumference; Body Composition; Meal Replacement

\section{Abbreviations and Acronyms}

CB: Special K Cereal + Nutrient Bar; CBW: Special K Cereal + Special K Waffle + Special K Nutrient Bar; CR: Special K Cereal alone; RTEC: Ready-To-Eat-Cereal; SD: Standard Deviation; SPK: Special K; WGMD: Weighted Group Mean Differences

\section{Introduction}

Overweight and obesity prevalence has increased markedly worldwide over the past several decades [1], presenting a major threat to the health of the global population. More than 1.4 billion adults are currently overweight, of which 200 million men and 300 million women are obese [1]. As overweight and obesity are established risk factors for serious co-morbidities, including cardiovascular disease, hypertension, Type 2 diabetes mellitus, and certain cancers, among other health conditions [2], identifying both environmental-level and individual-level strategies to help regulate body weight is imperative [3]. Since ways of preventing and treating overweight and obesity are complex, leading nutrition and health authorities recommend a multifaceted approach to successful and sustainable weight loss and weight maintenance [3-5]. A known and direct cause of obesity is energy imbalance [3]; therefore, decreasing energy intake and increasing energy expenditure are mainstays of evidence-based behavioral interventions [6]. One specific strategy to reduce energy intake, thereby facilitating weight loss and weight maintenance, is to replace higher energy-dense meals with lower energy-dense, portion-controlled meals [7-9].

The Special $\mathrm{K}$ Challenge ${ }^{\mathrm{TM}}$ is a relatively simple and practical program in which participants replace two meals per day with Special $\mathrm{K}^{\circledast}$ low calorie meal replacements, including primarily Ready-To-Eat Cereal (RTEC), but also protein bars and protein shakes, while still selecting one sensible meal of their choice. Additional components of this program include skim milk-to consume with the cereal-low-calorie Special K snacks ${ }^{\circledR}$, such as protein snack bars or cereal bars (90-110 kcal per serving), and fruits and vegetables [10]. By helping individuals reduce their caloric intake with commercially available, lower energydense, and portion-controlled meals and snacks, the Special $\mathrm{K}$ Challenge $^{\mathrm{TM}}$ intervention can help participants either begin a weight loss program or to provide short-term weight loss for ongoing weight maintenance efforts. By design, the Special $\mathrm{K}$ Challenge ${ }^{\mathrm{TM}}$ intervention is a short-term program, and as such, 
is not intended to be followed long-term. Since motivation is an integral component of successful weight loss in both the short- and long-term [11,12], however, an initial weight loss experienced on the Special $\mathrm{K}$ Challenge $\mathrm{e}^{\mathrm{TM}}$ intervention could help motivate individuals to continue with their long-term weight control plans.

This analysis includes ten trials that have been conducted among overweight and obese, generally healthy adults across seven countries on three continents to examine the effects of the Special $\mathrm{K}$ Challenge $\mathrm{e}^{\mathrm{TM}}$ intervention on body weight and waist circumference over a 2-week period [13-22]. Six of these trials were Randomized Controlled Trials (RCTs) [13,14,15,18,19,21] and four were uncontrolled trials $[16,17,20,22]$. The objective of this meta-analysis is to examine the effects of a short-term weight loss program on body weight and waist circumference in ten trials conducted across seven countries.

\section{Methods}

\section{Identification of Trials}

Ten Special K Challenge ${ }^{\mathrm{TM}}$ intervention trials with available results were located, four of which have been published in the peer-reviewed literature and identified in PubMed [14,17-19], and were included in this meta-analysis. All ten trials [13-22] examined the effect of the Special $\mathrm{K}$ Challenge ${ }^{\mathrm{TM}}$ intervention on body weight, while all trials but one [18] evaluated change in waist circumference. The studies were conducted in free-living generally healthy, overweight and obese adult populations across seven countries, including France [13], Ireland [22], Mexico $[15,21]$, Spain [19], the United Kingdom [16,17], the United States $[14,18]$, and Venezuela [20]. The six unpublished intervention trials were independent trials funded by Kellogg ${ }^{\circledR}$, conducted by five universities and one contract research organization: Loughborough University in the United Kingdom [16]; Universidad Autónoma de Querétaro in Mexico [15]; Carabobo University in Venezuela [20]; Universidad IberoamericanaSante Fe in Mexico [21]; University of Limerick in Ireland [22]; and Optimed, a contract research organization in France [13]. This review and meta-analysis follows the PRISMA statement for preferred reporting [23].

\section{Data extraction and quality assessment}

For this meta-analysis, data were extracted from peerreviewed publications for four studies[14,17-19], original datasets plus internal reports for three trials [15,16,21] (thus, six sources for these three trials), and internal reports alone for the remaining three trials $[13,20,22]$. If more than one source was available for a study, the following hierarchy was used for data extraction (assuming sufficient data were available in one source):

- $\quad$ Peer-reviewed publication;

- $\quad$ Original dataset; and

- Internal report.

The following information was extracted from each intervention study: author; year of publication, report, or original datafile; country; baseline demographic and health characteristics (age, sex, and body mass index); study duration; details regarding intervention and control regimens (if applicable); Special $\mathrm{K}^{\circledR}$ cereal/RTEC serving size; sample size per group (enrollees and completers); and means and Standard Deviations (SD) of changes in the outcome from baseline to the end of 2 weeks for all study arms. Eligible outcomes included body weight and waist circumference. Details regarding the intervention regimen included the specific type of cereal (i.e., Special $\mathrm{K}^{\circledR}$ cereal or other Kellogg's ${ }^{\circledast}$ RTEC), the timing and number of Special $K^{\circledast}$ cereal/ RTEC meals, and the amount of other recommended foods and beverages (e.g., milk, nutrient bars, and fruit). If provided, results from both per-protocol analyses (study completers) and intentto-treat analyses (study enrollees) were extracted. When SDs of change were unavailable, methods described in the Cochrane Handbook for Systematic Reviews of Interventions [24] were relied upon to calculate or estimate SDs from other reported statistics in the published papers, original data files, or reports (e.g., SDs were calculated from standard errors, confidence intervals (CI), $t$-values, or $p$-values). Two reviewers abstracted individual study information independently to ensure qualitycontrol. Extracted data were then reviewed jointly to resolve any discrepancies.

\section{Statistical analysis}

Meta-analyses were performed using random effects modeling with Comprehensive Meta-Analysis Software [25]. Random effects models were used to accommodate differences in subject or intervention characteristics, as well as countryspecific differences, which could have impacted the results. All meta-analysis models generated Weighted Group Mean Differences (WGMD) in body weight (kg) or waist circumference (cm), as well as 95\% CIs and corresponding $p$-values for heterogeneity. Outcome data measured on different scales were converted to the same unit (e.g., pounds to $\mathrm{kg}$ and inches to $\mathrm{cm}$ ) to ensure comparability between studies [24]. The meta-analysis models used the per-protocol results from all trials for greater comparability because only one study provided intent-to-treat results in addition to the per-protocol findings [25]. Each study was weighted by the inverse of the within-study error variance plus the between-study variance [26].

The primary meta-analyses evaluated the effect of the Special K Challenge ${ }^{\mathrm{TM}}$ intervention on body weight and waist circumference, consistently measured as the narrowest part of the torso, from baseline to the end of 2 weeks (within-group analysis) and compared intervention to control (between-group analysis), where applicable. The within-group analysis included 13 study arms because the trial by Wal et al. [14] had three different Special K Challenge ${ }^{\mathrm{TM}}$ arms and the trial by Mattes [18] had two intervention arms-a Special $\mathrm{K}$ Challenge ${ }^{\mathrm{TM}}$ arm and an arm that consumed a variety of Kellogg ${ }^{\circledR}$ brand RTECs. In the between-group analysis, results data from the comparison of only one study arm vs. control from each of these studies $[14,18]$ were included to avoid double-counting results. The study arm 
selected was the one most comparable to the interventions in the other included studies-i.e., the Special K Challenge ${ }^{\mathrm{TM}}$ cereal arm (without Special K Challenge ${ }^{\mathrm{TM}}$ waffles or bars) in the study by Wal et al. [14] and the Special K Challenge ${ }^{\mathrm{TM}}$ cereal arm in the study by Mattes [18]. Subgroup meta-analyses were performed among women only and by serving size of Special $\mathrm{K}^{\circledast}$ cereal/ RTEC (30/31 g vs. 45 g). These analyses examined change from baseline since there were insufficient studies with a control arm for a between-group analysis of these subgroups. There were also insufficient data to examine men only. $P<0.05$ was used to determine statistical significance.

\section{Results}

\section{Study characteristics}

Primary characteristics of the intervention trials are provided in Table 1: six of these trials were RCTs $[13,15,18,19,21]$ and four were uncontrolled trials $[16,17,20,22]$. A total of 545 participants were included in the within-group (change-from-baseline) metaanalysis of the Special $\mathrm{K}$ Challenge ${ }^{\mathrm{TM}}$ intervention and body weight; 458 participants (232 in the intervention and 226 in the control) were included in the between-group meta-analysis. Participant retention at 2 weeks, the endpoint used in this metaanalysis, was $79 \%$ in the intervention group (545 completers of the 694 enrollees). In the control group, participant retention was $74 \%$ (226 completers of the 306 enrollees). All trials collected outcome data at 2 weeks, or 17 days in the case of Vadillo et al [21]. Individual trial size ranged from 22 [17] to 137 adults [14]. Mean Body Mass Index (BMI) across the studies ranged from 27.7 [13] to $36.4 \mathrm{~kg} / \mathrm{m}^{2}$ [14]. Two studies [15,19] were conducted in women only; the remaining studies were conducted in both men and women. Four studies presented separate results for men and

Table 1: Characteristics of the intervention trials included in the meta-analysis.

\begin{tabular}{|c|c|c|c|c|c|c|c|c|c|c|}
\hline \multirow[b]{2}{*}{$\begin{array}{l}\text { Author, } \\
\text { year }^{\mathrm{a}}\end{array}$} & \multirow[b]{2}{*}{ Country } & \multirow[b]{2}{*}{$\begin{array}{l}\text { Sex } \\
(F / M)\end{array}$} & \multirow[b]{2}{*}{$\begin{array}{l}\text { BMI, } \\
\mathrm{kg} / \mathrm{m}^{2} \\
(\text { mean })\end{array}$} & \multicolumn{5}{|c|}{ Intervention details } & \multirow[b]{2}{*}{ Control } & \multirow[b]{2}{*}{$\begin{array}{l}\text { No. } \\
\text { completed / } \\
\text { no. enrolled }\end{array}$} \\
\hline & & & & Intervention & $\begin{array}{l}\text { RTEC (g) x } \\
\text { no. meals }\end{array}$ & $\begin{array}{l}\text { Skim or } \\
\text { semi-skim } \\
\text { milk (mL) } \mathrm{x} \\
\text { no. meals }\end{array}$ & other food & $\begin{array}{l}\text { No. } \\
\text { completed / } \\
\text { no. enrolled }\end{array}$ & & \\
\hline $\begin{array}{l}\text { Garcia et al. } \\
2012 \text { [15] }\end{array}$ & Mexico & $124 / 0$ & 30.5 & SPK cereal & $\begin{array}{l}45 \mathrm{~g} \mathrm{x} 2 \\
\text { meals }\end{array}$ & $\begin{array}{l}240 \text { mL x } 2 \\
\text { meals }\end{array}$ & Fruit & 59 / 84 & $\begin{array}{l}\text { Basic nutrition } \\
\text { education }\end{array}$ & 65 / 84 \\
\hline $\begin{array}{l}\text { Walton, } \\
2011 \text { [22] }\end{array}$ & Ireland & $12 / 12$ & 28.6 & SPK cereal & $\begin{array}{l}30 \mathrm{~g} \mathrm{x} 2 \\
\text { meals }\end{array}$ & $\begin{array}{l}125 \text { mL x } 2 \\
\text { meals }\end{array}$ & $\begin{array}{l}\text { Fruit, SPK } \\
\text { snacks }\end{array}$ & $24 / 24$ & - & - \\
\hline \multirow{3}{*}{$\begin{array}{l}\text { Wal et al. } \\
2007 \text { [14] }\end{array}$} & \multirow{3}{*}{ US } & \multirow{3}{*}{94 / 13} & \multirow{3}{*}{36.4} & $\begin{array}{l}\text { (1) SPK cereal, } \\
\text { SPK nutrient bar }\end{array}$ & \multirow{3}{*}{$\begin{array}{l}31 \mathrm{~g} \times 2 \\
\text { meals }\end{array}$} & \multirow{3}{*}{$\begin{array}{l}167 \mathrm{~mL} \times 2 \\
\text { meals }\end{array}$} & \multirow{3}{*}{ Fruit } & \multirow{3}{*}{$107 / 124$} & \multirow{3}{*}{ Usual diet } & \multirow{3}{*}{$36 / 40$} \\
\hline & & & & $\begin{array}{l}\text { (2) SPK cereal, } \\
\text { SPK waffle, SPK } \\
\text { nutrient bar }\end{array}$ & & & & & & \\
\hline & & & & (3) SPK cereal & & & & & & \\
\hline $\begin{array}{l}\text { Ortega et al. } \\
2005 \text { [19] }\end{array}$ & Spain & $67 / 0$ & 28.6 & $\begin{array}{l}\text { SPK cereal, } 2 \text { SPK } \\
\text { nutrient bars }\end{array}$ & $\begin{array}{l}30 \mathrm{~g} \times 1 \\
\text { meal } 40- \\
60 \mathrm{~g} \times 1 \\
\text { meal }\end{array}$ & $\begin{array}{l}125 \mathrm{~mL} \\
\text { breakfast, } \\
200 \mathrm{~mL} \\
\text { dinner }\end{array}$ & $\begin{array}{l}\text { Fruit or } \\
100 \% \text { juice }\end{array}$ & $30 / 31$ & $\begin{array}{l}\text { Increased } \\
\text { vegetable intake } \\
\text { to } 3 \text { servings/day }\end{array}$ & $32 / 36$ \\
\hline $\begin{array}{l}\text { Hooper, } \\
2003 \text { [16] }\end{array}$ & UK & $57 / 37$ & 32.4 & Variety of RTEC & $\begin{array}{l}45 \mathrm{~g} \times 2 \\
\text { meals }\end{array}$ & $\begin{array}{l}125 \text { mL x } 2 \\
\text { meals }\end{array}$ & - & $94 / 160$ & - & - \\
\hline \multirow{2}{*}{$\begin{array}{l}\text { Mattes, } 2002 \\
{[18]}\end{array}$} & \multirow{2}{*}{ US } & \multirow[b]{2}{*}{$47 / 9$} & \multirow[b]{2}{*}{29.2} & (1) SPK cereal & \multirow{2}{*}{$\begin{array}{l}45 \mathrm{~g} \mathrm{x} 2 \\
\text { meals }\end{array}$} & \multirow{2}{*}{$\begin{array}{l}167 \text { mL x } 2 \\
\text { meals }\end{array}$} & \multirow[b]{2}{*}{ Fruit } & \multirow[b]{2}{*}{$56 / 70$} & \multirow[b]{2}{*}{ Usual diet } & \multirow[b]{2}{*}{$26 / 36$} \\
\hline & & & & $\begin{array}{l}\text { (2) Variety of } \\
\text { RTEC }\end{array}$ & & & & & & \\
\hline $\begin{array}{l}\text { Solano et al. } \\
2001 \text { [20] }\end{array}$ & $\begin{array}{l}\text { Venezu- } \\
\text { ela }\end{array}$ & $65 / 12$ & 29.6 & SPK cereal & $\begin{array}{l}30 \mathrm{~g} \times 2 \\
\text { meals }\end{array}$ & $\begin{array}{l}125 \text { mL x } 2 \\
\text { meals }\end{array}$ & $\begin{array}{l}\text { Fruit, SPK } \\
\text { snacks }\end{array}$ & 77 / 91 & - & - \\
\hline $\begin{array}{l}\text { Vadillo- } \\
\text { Ortega et al. } \\
2001 \text { [21] }\end{array}$ & Mexico & $28 / 12$ & 28.0 & $\begin{array}{l}\text { Variety RTEC } \\
\text { alone }(10 \text { days }) \\
\text { RTEC }+ \text { SPK cereal } \\
(7 \text { days)c }\end{array}$ & $\begin{array}{l}45 \mathrm{~g} \times 1 \\
\text { meal }(10 \\
\text { days) or } 2 \\
\text { meals ( } 7 \\
\text { days) }\end{array}$ & $\begin{array}{l}240 \text { mL x } 1 \text { or } \\
2 \text { meals }\end{array}$ & Fruit & $17 / 22$ & $\begin{array}{l}\text { Usual diet with } \\
\text { added complex } \\
\text { carbohydrate, } \\
\text { fruit }\end{array}$ & 7 / 18 \\
\hline $\begin{array}{l}\text { Kirk et al. } \\
2000 \text { [17] }\end{array}$ & UK & $16 / 6$ & 31.0 & Variety of RTEC & $\begin{array}{l}45 \mathrm{~g} \times 2 \\
\text { meals }\end{array}$ & $\begin{array}{l}125 \text { mL x } 2 \\
\text { meals }\end{array}$ & - & $22 / 29$ & - & - \\
\hline \multicolumn{11}{|c|}{$\begin{array}{l}\text { Abbreviations: RTEC: Ready-To-Eat Cereal; SPK: Special K } \\
\text { a Year of publication, if available; otherwise, year of report or original data file. } \\
\text { b All RTEC was Kellogg brand. }\end{array}$} \\
\hline
\end{tabular}


women, as well as combined results $[13,16,21,22]$.

Ten of the individual intervention arms provided Kellogg ${ }^{\circledR}$ brand RTECs, with six [14,15,18-20,22] providing only Special $\mathrm{K}^{\circledR}$ cereal and three intervention arms [16-18] providing other Kellogg ${ }^{\circledR}$ brand RTECs. Vadillo et al. [21] included other Kellogg ${ }^{\circledR}$ brand RTECs for one meal and Special $\mathrm{K}^{\circledR}$ for the other meal. The cereal serving size was 30 or $31 \mathrm{~g}$ per arm [14,20,22], 45 g per arm [15-18,21], a combination of $30 \mathrm{~g}$ and $45 \mathrm{~g}$ [13],or a combination of $30 \mathrm{~g}$ and 40-60 g [19]. Skim or semi-skim milk was a part of the intervention in all trials, with servings ranging from $125 \mathrm{~mL}$ to $240 \mathrm{~mL}$ per meal. A serving of fruit was part of the intervention in 10 of the study arms (7 trials) [14,15,18-22], and Special K Challenge ${ }^{\mathrm{TM}}$ snacks or nutrient bars were a part of the intervention in 4 study arms ( 3 trials) $[14,20,22]$. The control regimens in the six studies with controls arms were "usual diet" $[13,14,21]$, increased vegetable intake to three servings per day[19], basic nutrition education [15], or "usual diet" with added complex carbohydrates and fruit [21].

\section{Meta-analysis results}

Figure 1 shows the effect size (WGMD), 95\% CI, and precision of each study from the meta-analysis of trials examining the Special K Challenge ${ }^{\mathrm{TM}}$ intervention and change in body weight from baseline, among all subjects (forest plot A), women only (forest plot B), and by serving size (forest plot C). All weighted mean reductions in body weight calculated in the meta-analysis were statistically significant. Results from each individual trial

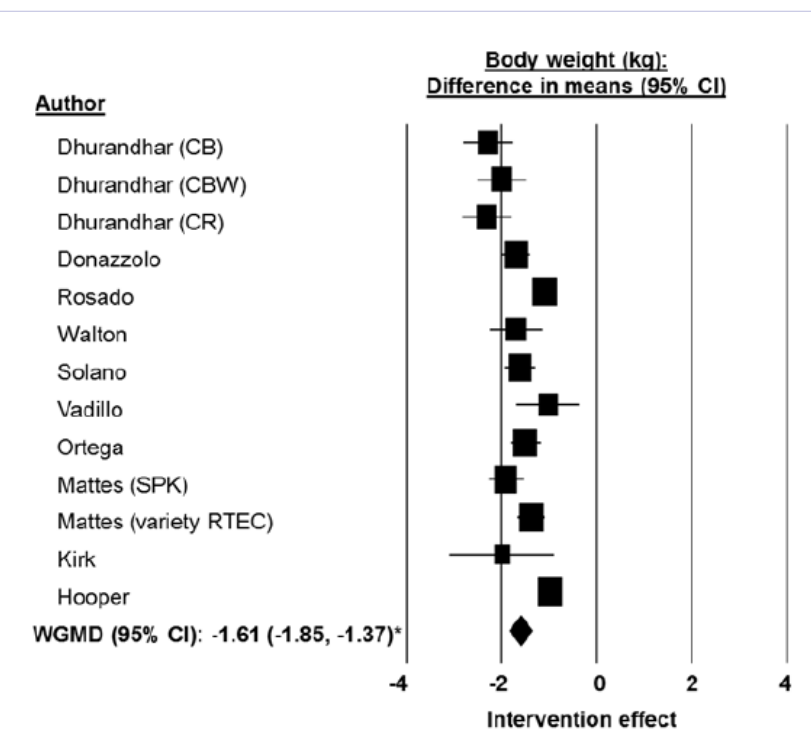

Figure 1a: Forest plots depicting the change in body weight $(\mathrm{kg})$ from baseline in the RTEC/SPK intervention, among all subjects

Squares represent mean change in body weight within the individual studies;

Horizontal lines represent $95 \%$ CIs

Square size is proportional to study weight;

Diamonds represent the weighted group mean changes (WGMD)

RTEC: Ready to Eat Breakfast Cereal; SPK: Special K Cereal; CB: SPK cereal plus SPK nutrient bar; CBW: SPK cereal, SPK waffle, plus SPK nutrient bar; CR: SPK cereal only. ${ }^{*} p<0.05$

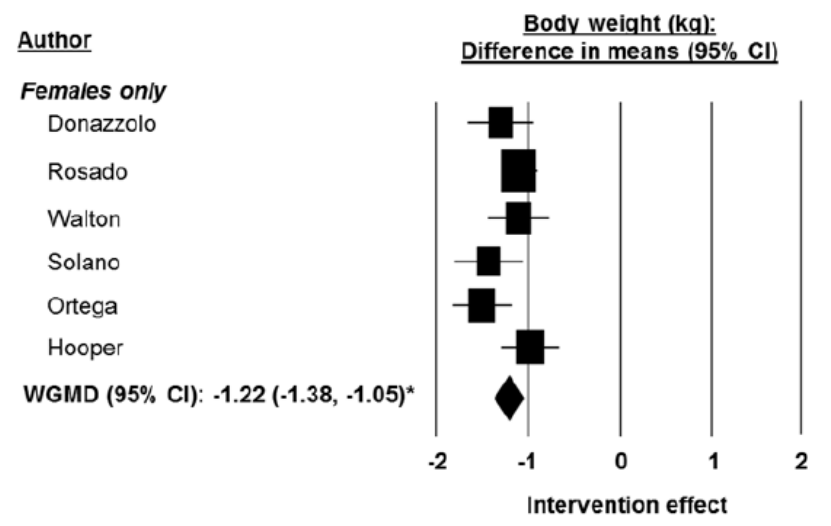

Figure 1b: Forest plots depicting the change in body weight (kg) from baseline in the RTEC/SPK intervention, females only

Squares represent mean change in body weight within the individual studies;

Horizontal lines represent 95\% CIs;

Square size is proportional to study weight;

Diamonds represent the weighted group mean changes (WGMD) RTEC: Ready to Eat Breakfast Cereal; SPK: Special K Cereal; CB: SPK cereal plus SPK nutrient bar; CBW: SPK cereal, SPK waffle, plus SPK nutrient bar; CR: SPK cereal only. ${ }^{*} p<0.05$

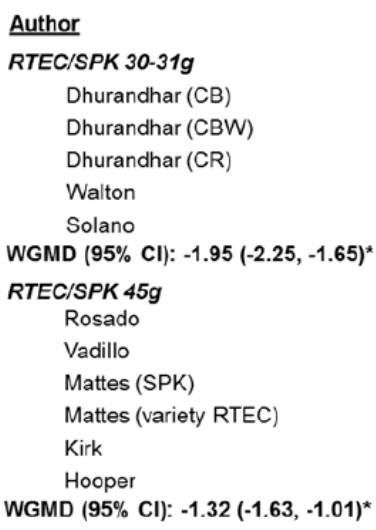
Difference in means $195 \% \mathrm{Cl}$

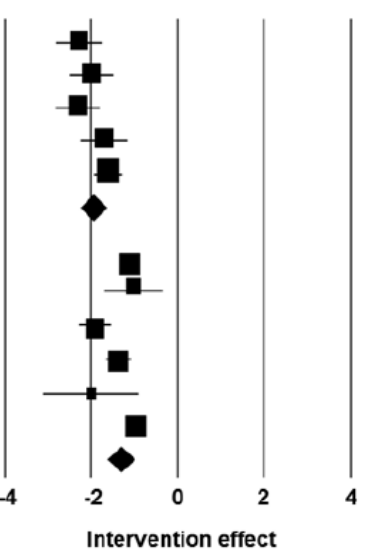

Figure 1c: Forest plots depicting the change in body weight (kg) from baseline in the RTEC/SPK intervention and by dose

Squares represent mean change in body weight within the individual studies;

Horizontal lines represent 95\% CIs;

Square size is proportional to study weight;

Diamonds represent the weighted group mean changes (WGMD) RTEC: Ready to Eat Breakfast Cereal; SPK: Special K Cereal; CB: SPK cereal plus SPK nutrient bar; CBW: SPK cereal, SPK waffle, plus SPK nutrient bar; CR: SPK cereal only.* $p<0.05$

consistently showed reductions in body weight (Table 2). In the meta-analysis of all subjects, the Special $\mathrm{K}$ Challenge $\mathrm{T}^{\mathrm{TM}}$ intervention reduced body weight by $1.61 \mathrm{~kg}(95 \% \mathrm{CI}:-1.85$, -1.37). Among women, the Special K Challenge ${ }^{\mathrm{TM}}$ intervention decreased body weight by $1.22 \mathrm{~kg}(95 \% \mathrm{CI}:-1.38,-1.05)$. The 
Table 2: Data summary of the individual intervention trials included in the meta-analysis.

\begin{tabular}{|c|c|c|c|c|c|c|c|c|}
\hline \multirow{3}{*}{ Author, year ${ }^{a}$} & \multicolumn{4}{|c|}{ Body weight (kg): change from baseline } & \multicolumn{4}{|c|}{ Waist circumference $(\mathrm{cm})$ : change from baseline } \\
\hline & \multicolumn{2}{|c|}{ Intervention } & \multicolumn{2}{|c|}{ Control } & \multicolumn{2}{|c|}{ Intervention } & \multicolumn{2}{|c|}{ Control } \\
\hline & Mean & SD & Mean & SD & Mean & SD & Mean & SD \\
\hline Garcia et al. 2012 [15] & -1.10 & 0.98 & -0.60 & 0.82 & -2.40 & 2.94 & -1.90 & 3.09 \\
\hline Walton, 2011 [22] & -1.70 & 1.40 & - & - & -1.90 & 1.70 & - & - \\
\hline Females & -1.10 & 0.60 & - & - & -1.60 & 1.40 & - & - \\
\hline Males & -2.30 & 1.70 & - & - & -2.30 & 1.90 & - & - \\
\hline \multirow{3}{*}{ Wal et al. $2007^{\mathrm{b}}[14]$} & $-2.28(\mathrm{CB})$ & 1.58 & 0.23 & 1.25 & $-3.45(\mathrm{CB})$ & 2.42 & -0.11 & 1.26 \\
\hline & $-2.00(\mathrm{CBW})$ & 1.55 & 0.23 & 1.25 & $-2.99(\mathrm{CBW})$ & 2.55 & -0.11 & 1.26 \\
\hline & $-2.31(\mathrm{CR})$ & 1.52 & 0.23 & 1.25 & $-3.08(\mathrm{CR})$ & 1.99 & -0.11 & 1.26 \\
\hline Donazzolo, 2006 [13] & -1.69 & 1.17 & 0.16 & 1.01 & -1.10 & 1.30 & 0.20 & 0.60 \\
\hline Females & -1.30 & 1.00 & 0.20 & 1.00 & - & - & - & - \\
\hline Males & -2.10 & 1.20 & 0.10 & 1.10 & - & - & - & - \\
\hline Ortega et al. 2005 [19] & -1.50 & 0.90 & -0.90 & 0.60 & -2.20 & 2.40 & -1.40 & 2.77 \\
\hline Hooper, 2003 [16] & -0.97 & 1.07 & - & - & -2.03 & 2.13 & - & - \\
\hline Females & -0.98 & 1.21 & - & - & -1.91 & 2.26 & - & - \\
\hline Males & -0.95 & 0.91 & - & - & -2.09 & 1.89 & - & - \\
\hline \multirow{2}{*}{ Mattes, $2002^{c}[18]$} & $-1.91(\mathrm{SPK})$ & 1.01 & -0.08 & 0.76 & - & - & - & - \\
\hline & -1.37 (RTEC) & 0.79 & -0.08 & 0.76 & - & - & - & - \\
\hline Solano et al. 2001 [20] & -1.61 & 1.52 & - & - & -2.91 & 5.41 & - & - \\
\hline Females & -1.43 & 1.55 & - & - & -2.79 & 5.72 & - & - \\
\hline Males & -2.59 & 0.79 & - & - & -3.58 & 3.37 & - & - \\
\hline Vadillo-Ortega et al. 2001 [21] & -1.02 & 1.43 & 0.37 & 0.83 & -1.10 & 2.53 & -2.07 & 3.43 \\
\hline Kirk et al. $2000[17]$ & -2.00 & 2.65 & - & - & -1.00 & 2.40 & - & - \\
\hline \multicolumn{9}{|c|}{$\begin{array}{l}\text { Abbreviations: RTEC: Ready-To-Eat Cereal; SD: Standard Deviation; SPK: Special K } \\
\text { a Year of publication is shown, if available; otherwise, year of report or original data file is provided. } \\
\text { b Study included three intervention arms: SPK cereal + nutrient bar (CB); SPK cereal + SPK waffle + SPK nutrient bar (CBW); and SPK cereal alon } \\
\text { (CR). } \\
\text { 'c Study included two intervention arms: SPK cereal (SPK) and variety of RTEC (RTEC). }\end{array}$} \\
\hline
\end{tabular}

meta-analysis by serving size revealed reductions of $1.95 \mathrm{~kg}$ (95\% CI: -2.25, -1.65) with 30-31g RTEC per meal and 1.32 kg (95\% CI: $-1.63,-1.01)$ with 45g RTEC per meal. As shown by the non-overlapping 95\% CIs and corresponding $p$-value for heterogeneity $(p-\mathrm{H}=0.005)$, body weight reduction in the intervention group differed significantly by serving size, with a larger reduction seen with the smaller serving size.

Figure 2 depicts the effects of the Special $\mathrm{K}$ Challenge ${ }^{\mathrm{TM}}$ intervention on change in waist circumference from baseline, among all subjects (forest plot A), women only (forest plot B), and by serving size (forest plot $\mathrm{C}$ ). All weighted mean reductions in waist circumference generated by the meta-analysis models were statistically significant. Results from each individual study also consistently found a reduction in waist circumference with the Special K Challenge ${ }^{\mathrm{TM}}$ intervention (Table 2). The Special $\mathrm{K}$ Challenge $^{\mathrm{TM}}$ intervention decreased waist circumference by 2.19 cm (95\% CI: $-2.72,-1.66)$ among all subjects and by $2.06 \mathrm{~cm}(95 \%$ CI: -2.41, -1.71) among women. Subgroup analysis by serving size revealed reductions of 2.84 (95\% CI: -3.42, -2.26) with the smaller serving of 30-31 g RTEC per meal and $1.77 \mathrm{~cm}(95 \%$ CI: $-2.37,-1.18$ ) with the larger serving of 45 g RTEC per meal. Although the $95 \%$ CIs slightly overlapped, the corresponding $p$-value for heterogeneity was statistically significant $(p-\mathrm{H}=$ 0.012 ), suggesting possible effect modification by serving size.

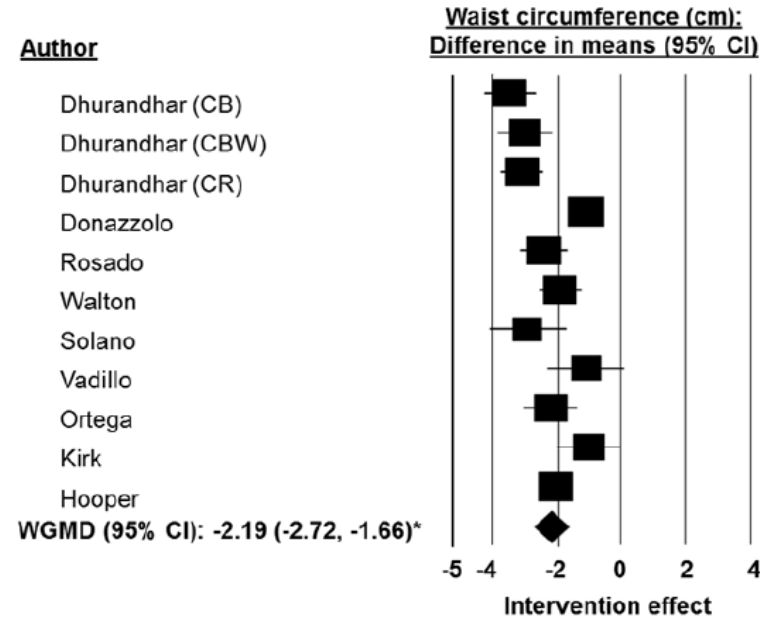

Figure 2a: Forest plots depicting the change in waist circumference (cm) from baseline in the RTEC/SPK intervention, among all subjects Squares represent mean change in body weight within the individual studies; Horizontal lines represent 95\% CIs;

Square size is proportional to study weight;

Diamonds represent the weighted group mean changes (WGMD)

RTEC: Ready to Eat Breakfast Cereal; SPK: Special K Cereal; CB: SPK cereal plus SPK nutrient bar; CBW: SPK cereal, SPK waffle, plus SPK nutrient bar; CR: SPK cereal only. ${ }^{*} p<0.05$ 


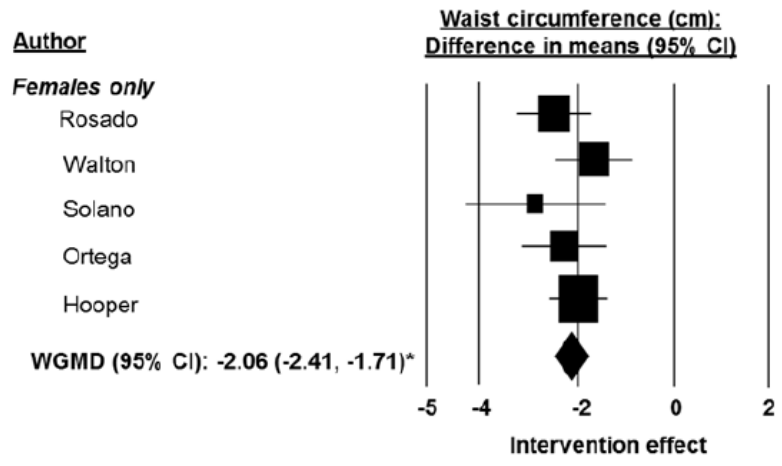

Figure 2b: Forest plots depicting the change in waist circumference $(\mathrm{cm})$ from baseline in the RTEC/SPK intervention, females only Squares represent mean change in body weight within the individual studies; Horizontal lines represent $95 \%$ CIs;

Square size is proportional to study weight;

Diamonds represent the weighted group mean changes (WGMD) RTEC: Ready to Eat Breakfast Cereal; SPK: Special K Cereal; CB: SPK cereal plus SPK nutrient bar; CBW: SPK cereal, SPK waffle, plus SPK nutrient bar; CR: SPK cereal only. ${ }^{*} p<0.05$

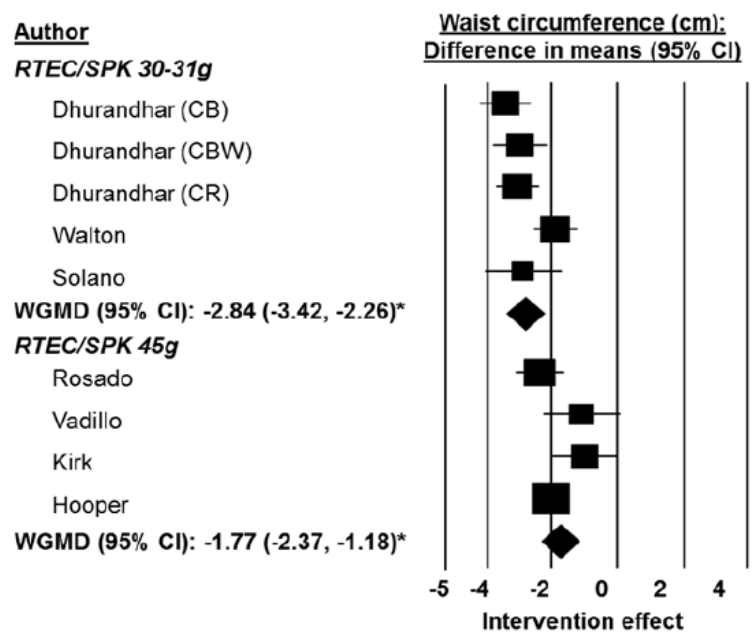

Figure 2c: Forest plots depicting the change in waist circumference $(\mathrm{cm})$ from baseline in the RTEC/SPK intervention and by dose Squares represent mean change in body weight within the individual studies; Horizontal lines represent 95\% CIs;

Square size is proportional to study weight;

Diamonds represent the weighted group mean changes (WGMD) RTEC: Ready to Eat Breakfast Cereal; SPK: Special K Cereal; CB: SPK cereal plus SPK nutrient bar; CBW: SPK cereal, SPK waffle, plus SPK nutrient bar; CR: SPK cereal only. ${ }^{*} p<0.05$

The meta-analysis results examining the effects of the Special $\mathrm{K}$ Challenge ${ }^{\mathrm{TM}}$ intervention, compared to control, on body weight and waist circumference are illustrated in Figure 3. These results were consistent with those from the within-group analyses. Compared to control, the Special $\mathrm{K}$ Challenge ${ }^{\mathrm{TM}}$ intervention resulted in a statistically significant reduction in both body weight $(-1.43 \mathrm{~kg}$; 95\% CI: $-2.10,-0.76)$ and waist circumference $(-1.20 \mathrm{~cm} ; 95 \% \mathrm{CI}:-2.20,-0.20)$. There were insufficient data to examine the effects of the Special $\mathrm{K}$ Challenge ${ }^{\mathrm{TM}}$ intervention compared to control by subgroups.

\section{Discussion}

The present meta-analysis supports participation in the Special $\mathrm{K}$ Challenge ${ }^{\mathrm{TM}}$ program to reduce body weight and waist circumference among generally healthy, overweight adult populations. The consistent, statistically significant weighted mean reductions in body weight and waist circumference among all subjects, population subgroups, and RTEC serving sizes (30-31 g and $45 \mathrm{~g}$ per meal) demonstrates that the Special $\mathrm{K}$ Challenge ${ }^{\mathrm{TM}}$ program is an effective, short-term approach for reducing body weight and waist circumference. The meta-

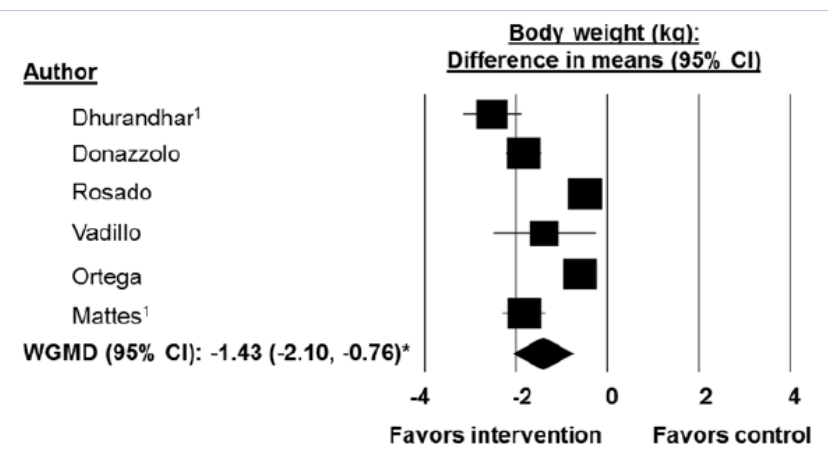

Figure 3a: Forest plots depicting the change in body weight (kg) in the SPK intervention, compared to control.

Squares represent mean change in body weight within the individual studies; Horizontal lines represent 95\% CIs.

Square size is proportional to study weight.

Diamonds represent the weighted group mean changes (WGMD).

RTEC: Ready to Eat Breakfast Cereal; SPK: Special K Cereal; WGMD: Weighted Group Mean Difference.

${ }^{1}$ Includes study arm that received SPK cereal only. ${ }^{*} p<0.05$

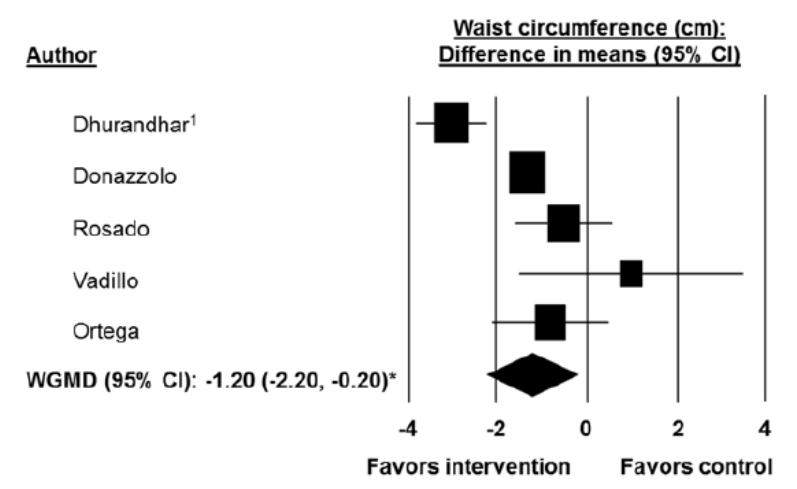

Figure 3b: Forest plots depicting the change in waist circumference $(\mathrm{cm})$ in the SPK intervention, compared to control.

Squares represent mean change in body weight within the individual studies; Horizontal lines represent 95\% CIs.

Square size is proportional to study weight.

Diamonds represent the weighted group mean changes (WGMD).

RTEC: Ready to Eat Breakfast Cereal; SPK: Special K Cereal; WGMD:

Weighted Group Mean Difference.

${ }^{1}$ Includes study arm that received SPK cereal only. ${ }^{*} p<0.05$ 
analysis that examined change-from-baseline in body weight among participants in the Special $\mathrm{K}_{\text {Challenge }}{ }^{\mathrm{TM}}$ intervention, and the meta-analysis comparing the effects of the Special $\mathrm{K}$ Challenge $^{\mathrm{TM}}$ intervention vs. control generated weighted mean body weight reductions that were similar in magnitude $(-1.61 \mathrm{~kg}$ and $-1.43 \mathrm{~kg}$, respectively). The change-from-baseline decrease in waist circumference $(-2.19 \mathrm{~cm})$ was larger than the decrease from the meta-analysis comparing the Special $\mathrm{K}$ Challenge ${ }^{\mathrm{TM}}$ intervention to control $(-1.20 \mathrm{~cm})$, although both were in the same direction and statistically significant. Further support for the Special $\mathrm{K}$ Challenge ${ }^{\mathrm{TM}}$ programs comes from an evaluation of the individual trials [13-22], each of which found statistically significant decreases in body weight and waist circumference from baseline, except for Mattes [18], which did not examine waist circumference as an outcome. The meta-analysis results, in addition to the consistency in findings among the individual studies conducted across seven countries on three continentsNorth America, South America, and Europe-indicate that the findings from this meta-analysis are generalizable to other generally healthy, overweight populations across different geographic regions.

The Special $\mathrm{K}$ Challenge $\mathrm{e}^{\mathrm{TM}}$ is designed to be a simple, 2-week program to help participants either begin a weight loss program or to provide short-term weight loss for ongoing weight maintenance efforts. The foundation of this program is the replacement of two meals per day with low calorie meal replacements, the core of which is breakfast cereals. Additional components of this program include skim milk, portion-controlled snacks, fruits, and vegetables. The Special $\mathrm{K}$ Challenge ${ }^{\mathrm{TM}}$ program relies on familiar, commercially-available breakfast cereal that is low in energy density but high in nutrient density [27-29]. The RTECs recommended in this program are good sources of many vitamins and minerals, including vitamins $A, B_{6}, B_{12}, C$, and $E$, folic acid, niacin, riboflavin, thiamin, iron, selenium, and zinc, and contribute no saturated fat while also providing approximately $6 \mathrm{~g}$ of protein [30]. Previous research has shown that RTEC is an important contributor to daily intakes of key vitamins and minerals as well as overall diet quality [27,29,31,32]. In addition, past analyses of data from national food intake surveys have found that individuals who consumed RTEC for breakfast, compared to those who skipped breakfast or consumed meat or eggs, or both, had a significantly lower BMI [32]. Furthermore, dietary patterns that include RTEC have been associated with a lower BMI [33].

The current findings highlight the effectiveness of a weightloss plan based on the principle of reducing energy intake through meal replacement and portion control. Accumulating evidence shows that reduction in energy intake, as opposed to a specific macronutrient composition, is the key tenet of successful weight loss [34]. A large randomized clinical trial of 811 participants found that energy-reduced diets of varying macronutrient composition-low or high fat, low or high in carbohydrates, and average or high protein-all resulted in significant weight loss after 2 years [34].

The Special K Challenge ${ }^{\mathrm{TM}}$ is not intended to be a long-term plan for weight loss and weight maintenance. Rather, the role of the Special $\mathrm{K}$ Challenge $\mathrm{T}^{\mathrm{TM}}$ is to provide an initial weight loss that could, in turn, improve motivation-an established, integral component of successful weight loss and weight maintenance $[11,12,35]$ - to adhere to a long-term plan that involves sustainable lifestyle-related behavioral changes. Moreover, many aspects of the Special $\mathrm{K}$ Challenge $\mathrm{e}^{\mathrm{TM}}$, including consumption of RTEC for breakfast and an overall low energy-dense, reducedcalorie, and low-fat diet, are consistent with the core tenets of successful weight loss among long-term weight loss maintainers. This diet is not driven primarily by a reduction in carbohydrate intake, which is often associated with short-term water loss in the first week of dieting. According to data from the National Weight Control Registry, a U.S. database of more than 4,000 individuals who have successfully maintained weight loss [36], the defining characteristics of this population is the regular consumption of breakfast and a low-calorie, low-fat diet, in addition to consistent eating patterns across weekdays and weekends and regular physical activity $[37,38]$.

The strengths of the present meta-analysis include the large total sample of participants, the diverse geographic representation of the study populations, and the comparability of the intervention arms (which reduces between-study variation). In addition, the inclusion of unpublished data helps overcome the potential problem of publication bias, which can arise due to the selective availability of published data [39]. Nevertheless, several limitations should be considered. Four of the included studies were uncontrolled trials $[16,17,20,22]$; therefore, changes in body weight and waist circumference in these trials cannot be fully attributed to the intervention, as the placebo effect remains possible [40]. The significant results in the analysis of only those trials with control arms, however, suggest that the Special K Challenge $^{\mathrm{TM}}$ intervention has a true effect on body weight and waist circumference. The retention rate in the intervention of $79 \%$ is comparable, and in some cases higher, to what has been documented in the literature [41,42], but suggests that the Special $\mathrm{K}_{\text {Challenge }} \mathrm{TM}^{\mathrm{TM}}$ intervention, similar to other diet interventions, may have to be modified to meet the needs of certain subgroups of the population. The present analysis is based on data from per-protocol analyses rather than intention-to-treat analyses. The potential for bias in the reported measures of association is possible; however, the relatively high retention rate minimizes the probability of observing spurious results.

\section{Conclusion}

In summary, the meta-analysis of RCTs and uncontrolled trials that examined the Special $\mathrm{K}$ Challenge ${ }^{\mathrm{TM}}$ intervention revealed statistically significant reductions in both body weight and waist circumference. Since waist circumference, performed correctly, is an indicator of abdominal fat $[43,44]$, these findings also suggest that abdominal fat may be reduced from the Special $\mathrm{K}_{\text {Challenge }} \mathrm{T}^{\mathrm{TM}}$ intervention. The consistent findings among all analyses, including that of all subjects, population subgroups, and RTEC serving sizes demonstrate that the Special $\mathrm{K}$ Challenge $\mathrm{P}^{\mathrm{TM}}$ intervention is effective for reducing body weight and waist circumference in the short-term. The simultaneous decrease in 
waist circumference with weight loss suggests that a reduction in abdominal fat results from the weight loss induced during the treatment. The crux of this program-meal replacement and portion-control-could be incorporated into long-term weight loss and weight maintenance plans. The consistency in findings and broad geographic representation of the trials, which were conducted across seven countries on three continents, indicates that the results from this meta-analysis are generalizable to other generally healthy, overweight populations across different geographic regions. Based on the available evidence, the Special $\mathrm{K}$ Challenge $\mathrm{e}^{\mathrm{TM}}$ is an effective approach to achieve short-term weight loss and smaller waist circumference among overweight individuals.

\section{References}

1. World Health Organization. Obesity and Overweight: Fact Sheet No. 311. Lyons, France: World Health Organization; 2013.

2. US Department of Health and Human Services. The Surgeon General's Call to Action to Prevent and Decrease Overweight and Obesity. Rockville, MD: US Government Printing Office; 2001.

3. Huang TT, Drewnosksi A, Kumanyika S, Glass TA. A systems-oriented multilevel framework for addressing obesity in the 21st century. Prev Chronic Dis. 2009; 6(3): A82.

4. EFSA Panel on Dietetic Products Nutrition and Allergies (NDA). Scientific opinion on the substantiation of health claims related to rye fibre and changes in bowel function (ED 825), reduction of postprandial glycaemic responses (ID 826) and maintenance of norma blood LDL-cholesterol concentrations (ID 827) pursuant to Article 13(1) of Regulation (EC) No 1924/2006. EFSA Journal 2011; 9: 22.

5. Seagle HM, Strain GW, Makris A, Reeves RS; American Dietetic Association. Position of the American Dietetic Association: weight management. J Am Diet Assoc. 2009;109(2): 330-46.

6. Laddu D, Dow C, Hingle M, Thomson C, Going S. A review of evidencebased strategies to treat obesity in adults. Nutr Clin Pract. 2011; 26(5): 512-25. doi: 10.1177/0884533611418335.

7. Hannum SM, Carson L, Evans EM, Canene KA, Petr EL, Bui L, et al . Use of portion-controlled entrees enhances weight loss in women. Obes Res. 2004; 12(3): 538-46

8. Rolls BJ, Morris EL, Roe LS. Portion size of food affects energy intake in normal-weight and overweight men and women. Am J Clin Nutr. 2002; 76(6): 1207-13.

9. Rolls BJ, Roe LS, Meengs JS. Reductions in portion size and energy density of foods are additive and lead to sustained decreases in energy intake. Am J Clin Nutr. 2006; 83(1): 11-7.

10. Kellogg. Special K®. 2014.

11. Teixeira PJ, Mata J, Williams GC, Gorin AA, Lemieux S. Self-regulation, motivation, and psychosocial factors in weight management. J Obes. 2012; 2012: 582348. doi: 10.1155/2012/582348.

12. West DS, Gorin AA, Subak LL, Foster G, Bragg C, Hecht J, et al. A motivation-focused weight loss maintenance program is an effective alternative to a skill-based approach. Int J Obes (Lond). 2011; 35(2) 259-69. doi: 10.1038/ijo.2010.138.

13. Donnazollo Y. Evaluation of a hypocaloric diet including 2 daily intakes of Kellogg's product "Special K": Consequences on weight changes in healthy moderately overweight subjects. Kellogg, Data on File. 2005.
14. Wal JS, McBurney MI, Cho S, Dhurandhar NV. Ready-to-eat cereal products as meal replacements for weight loss. Int J Food Sci Nutr. 2007; 58(5): 331-40.

15. García S, Ronquillo D, García OP. [Use of Special-K® meal plan to promote fat and weight loss and maintain an adequate nutritional status in Mexican overweight and obese women]. Kellogg, Data on File. 2012

16. Hooper RH. [Body shape and clothing size changes following Kellogg's 2 week challenge]. Kellogg, Data on File. 2002.

17. Kirk TR. Role of dietary carbohydrate and frequent eating in bodyweight control. Proc Nutr Soc. 2000; 59(3): 349-58.

18. Mattes RD. Ready-to-eat cereal used as a meal replacement promotes weight loss in humans. J Am Coll Nutr. 2002; 21(6): 570-7.

19. Ortega RM, López-Sobaler AM, Rodríguez Rodríguez E, Bermejo LM, García González L, López Plaza B. [Response to a weight control program based on approximating the diet to its theoretical ideal]. Nutr Hosp. 2005; $20(6)$ : 393-402.

20. Solano L, Portillo Z, Marcano M, et al. Weight loss and maintenance through a diet high in carbohydrates. Kellogg, Data on File. 2001.

21. Vadillo-Ortega F, Perichard-Perera 0, Salinas-Deffis A. [Promotion of dietary carbohydrates as a method to maintain weight on a long term basis after an initial weight loss]. Kellogg, Data on File. 2001.

22. Walton J. The effects of the Special K Challenge on body composition and biomarkers of metabolic health in healthy adults. Kellogg, Data on File. 2011

23. Moher D, Liberati A, Tetzlaff J, Altman DG; PRISMA Group. Preferred reporting items for systematic reviews and meta-analyses: the PRISMA statement. Int J Surg. 2010; 8(5): 336-41. doi: 10.1016/j. ijsu.2010.02.007

24. Higgins JPT, Green S. Cochrane Collaboration. Cochrane Handbook for Systematic Reviews of Interventions. Hoboken, NJ: Wiley-Blackwell; 2008

25. Biostat. Comprehensive Meta-Analysis Software, Englewood, NJ: Biostat.

26. Borenstein M, Hedges LV, Higgins JP, Rothstein HR. A basic introduction to fixed-effect and random-effects model for meta-analysis. Res Synth Methods. 2010; 1(2): 97-111. doi: 10.1002/jrsm.12.

27. Galvin MA, Kiely M, Flynn A. Impact of ready-to-eat breakfast cereal (RTEBC) consumption on adequacy of micronutrient intakes and compliance with dietary recommendations in Irish adults. Public Health Nutr. 2003; 6(4): 351-63.

28. Thomas RG, Pehrsson PR, Ahuja JKC, Smieja E, Miller KB. Recent trends in ready-to-eat breakfast cereals in the U.S. 36th National Nutrient Databank Conference. Procedia Food Science. 2013; 2: 20-6.

29. van den Boom A, Serra-Majem L, Ribas L, Ngo J, Pérez-Rodrigo C, Aranceta J, et al. The contribution of ready-to-eat cereals to daily nutrient intake and breakfast quality in a Mediterranean setting. J Am Coll Nutr. 2006; 25(2): 135-43.

30.US Department of Agriculture. Agricultural Research Service USDA National Nutrient Database for Standard Reference. Release 26, Software v.1.3.1.

31. Barton BA, Eldridge AL, Thompson D, Affenito SG, Striegel-Moore RH, Franko DL, et al. The relationship of breakfast and cereal consumption to nutrient intake and body mass index: the National Heart, Lung, and Blood Institute Growth and Health Study. J Am Diet Assoc. 2005; 


\section{5(9): 1383-9.}

32. Cho S, Dietrich M, Brown CJ, Clark CA, Block G. The effect of breakfast type on total daily energy intake and body mass index: results from the Third National Health and Nutrition Examination Survey (NHANES III). J Am Coll Nutr. 2003; 22(4): 296-302.

33. Maskarinec G, Novotny R, Tasaki K. Dietary patterns are associated with body mass index in multiethnic women. J Nutr. 2000; 130(12): 3068-72.

34. Sacks FM, Bray GA, Carey VI, Smith SR, Ryan DH, Anton SD, et al Comparison of weight-loss diets with different compositions of fat, protein, and carbohydrates. N Engl J Med. 2009; 360(9): 859-73. doi: 10.1056/NEJMoa0804748.

35. Teixeira PJ, Silva MN, Mata J, Palmeira AL, Markland D. Motivation, self-determination, and long-term weight control. Int J Behav Nutr Phys Act. 2012; 9: 22. doi: 10.1186/1479-5868-9-22.

36. Hill JO, Wyatt H, Phelan S, Wing R. The National Weight Control Registry: is it useful in helping deal with our obesity epidemic? J Nutr Educ Behav. 2005; 37(4): 206-10.

37. Wing RR, Phelan S. Long-term weight loss maintenance. Am J Clin Nutr. 2005; 82(1 Suppl): 222S-225S.
38. Wyatt HR, Grunwald GK, Mosca CL, Klem ML, Wing RR, Hill JO. Longterm weight loss and breakfast in subjects in the National Weight Control Registry. Obes Res. 2002; 10(2): 78-82.

39. Hopewell S, McDonald S, Clarke M, Egger M. Grey literature in metaanalyses of randomized trials of health care interventions. Cochrane Database Syst Rev. 2007; (2): MR000010.

40.Piantadosi S. Clinical Trials: A Methodological Perspective, 2nd Edition. Volume 593. New York: Wiley; 2005.

41. Heshka S, Anderson JW, Atkinson RL, Greenway FL, Hill JO, Phinney $\mathrm{SD}$, et al. Weight loss with self-help compared with a structured commercial program: a randomized trial. JAMA. 2003; 289(14): 17928.

42. Tsai AG, Wadden TA. Systematic review: an evaluation of major commercial weight loss programs in the United States. Ann Intern Med. 2005; 142(1): 56-66.

43. Bosy-Westphal A, Booke CA, Blöcker T, Kossel E, Goele K, Later W, et al. Measurement site for waist circumference affects its accuracy as an index of visceral and abdominal subcutaneous fat in a Caucasian population. J Nutr. 2010; 140(5): 954-61. doi: 10.3945/jn.109.118737.

44. Grundy SM, Neeland IJ, Turer AT, Vega GL. Waist circumference as measure of abdominal fat compartments. J Obes. 2013; 2013: 454285. doi: 10.1155/2013/454285. 